\title{
EVALUATION OF THE CONTRIBUTION OF DIFFERENT PIG POPULATIONS TO THE GENETIC DIVERSITY OF THE LARGE WHITE BREED
}

\author{
N.A. Zinovieva ${ }^{1}$, V.R. Kharzinova ${ }^{1}$, E.I. Sizareva ${ }^{2}$, E.A. Gladyr'1, O.V. Kostyunina ${ }^{1}$, S.I. Lugovoi ${ }^{3}$, \\ V.A. Tapiha ${ }^{3}$, L.N. Gamko ${ }^{4}$ E.V. Ovseenko ${ }^{4}$, K.M. Shavyrina ${ }^{1}$, L.K. Ernst ${ }^{1}$ \\ ${ }^{1}$ All-Russia Research and Development Institute for Livestock Husbandry, RAAS, Dubrovitsy settlement 142132 , \\ Podolsk region, Moscow province, Russia \\ e-mail: nzinovieva@mail.ru \\ ${ }^{2}$ Znamensky Genetic Selection Center, Orel 302030, Russia \\ e-mail: sizareva@nsgc.ru \\ ${ }^{3}$ Nikolaev State Agrarian University, Nikolaev 54029, Ukraine \\ e-mail:lugovoy79@mail.ru \\ ${ }^{4}$ Bryansk State Agricultural Academy, Kokino settlement 243365, Vygonichsky region, Bryansk province, Russia \\ e-mail: bgsha@bgsha.com,cit@bgsha.com
}

Received July 19, 2012

S u m mary

The characteristic of the allele pool of the Large White and Yorkshire pig breeds using 11 microsatellites (S0155, S0355, S0386, SW72, SW951, S0101, SW240, SW857, S0228, SW911 and SW936) was done. The study was performed on 17 pig populations of Russian, Danish, Hungarian, Canadian, Lithuanian, German, Ukrainian and French origins $(n=837)$. The data were analyzed using GenAlEx $(v$. 6.4), Structure (v. 2.3.1) and Past (v. 2.15) software. It was shown that 24.2 per cent of the total microsatellite diversity was due to intra population differences $(R s t=0.242, p=0.01)$. Based on Fst and Rst (AMOVA) values the greater contribution of geographically distant and local populations into microsatellites diversity was observed. The cluster analysis performed according J.K. Pritchard (2000) and M. Nei (1983) showed that the cluster structure was in concordance with populations' origin.

Keywords: pig, Large White breed, Yorkshire, genetic diversity, microsatellites.

Dedicated to the memory of academician L.K. Ernst

Evaluation of genetic diversity of breeds requires the study of a greatest possible number of genetically isolated populations. In this regard, local populations can be particularly important, because they often carry unique alleles peculiar to indigenous cattle developed in conditions of relative geographic isolation $(1,2)$. In addition, allelic profiles of livestock breeds used in intensive farming are strongly influenced by strategies of selection and breeding work.

Large White is the most common pig breed in the world. In Russia, Large Whites represent more than $85 \%$ total livestock population, in France and Finland - about $63 \%$, in Poland - 60\%, in the UK - 50\% (3). The breed was established in England, the county of Yorkshire, in the middle of the XIX century. Originally called Yorkshire, it was later re-named to Large White by the English Royal Agricultural Society, though in some countries - breed importers it still has been known as Yorkshire.

In Russia, the first groups of English Large Whites were delivered in late 1870ies and early 1880iess, and later - in the period from 1923 to 1931 in order to restore domestic populations significantly reduced after the First World War (3). The formation of domestic Large White was significantly influenced by Schepkin lard-type pigs bred as a base livestock in all pig breeding farms at that time. According to Volume I of the Stud Book of Pigs published in 1932, about 30\% of the 48 recorded boars and over $60 \%$ of the 340 sows were of Schepkin bloods that, in turn, carried the bloods of Pavlinov half-breed pigs (4). In most of pig breeding farms, English Large Whites were used in crosses with local mix-bred pigs well adapted to local climatic conditions (5). In the 1920-1930ies, domestic Large Whites were represented by animals of pork and lard types. The first Soviet standard developed in 1934 by N.N. Zavadovsky intended breeding of the pork type swine. In the 1940ies, this standard was replaced by a new one aimed at production of lard-type pigs due to high economical demands for lard (6). To improve product quality and fattening, in following years there were performed crosses with fresh bloods of Large White and Yorkshire animals of English, Swedish, Dutch, Danish, French, and Canadian selection. The pedigree pigs were imported from England in 1947-1948, from Sweden and England - in 1970-1981, from the Netherlands - in 1982 (7). In the last decade, the increased demand for lean pork has led to a notable depopulation of lard-type Large Whites of domestic selection, because many breeding farms replaced them by improved pigs of foreign selection obtained from Canada (Canadian Centre for Swine Improvement, CCSI), Denmark (breeding farms - the participants of DanBred program organized by Danish Pig Research Centre), Ireland (Hermitage Genetics), Netherlands (Hypor BV, Topigs), France (Cooperl Ark Atlantique, France Hybrid), Germany (Rhg Hirshmann Hybrid GmbH) and other countries.

An important instrument for studies of populations' state and dynamics are DNA markers of various types, the most common of which are microsatellites (8). They've found a practical application in works on evaluation of allele pools of animal breeds, types and lines, as well as management of population structure (9-12).

The purpose of this research was to study the allele pool of domestic Large White pigs and assess the influence of individual populations on genetic diversity using microsatellites.

Technique. Samples of biological material (ear notches, preservative - 96\% ethanol) were obtained from 837 pigs of Large White and Yorkshire breeds belonging to 17 different populations.

Microsatellite analysis was performed for 11 loci (S0155, S0355, S0386, SW72, SW951, S0101, SW240, SW857, S0228, SW911, and SW936) using a test system for DNA examination in pigs (13). Separation and identification of amplification products was performed on a genetic analyzer AVI3130xl ("Applied Biosystems", USA) according to the manufacturer's guidelines.

Statistical calculations were conducted according to B. Weir (14) in Microsoft Excel 2007 with the plugin GenAlEx v. 6.4. The following characteristics were determined: average number of alleles, number of effective alleles per locus, observed and expected heterozygosity, fixation index $F_{\text {is }}$. Variability of microsatellites in the studied populations was estimated by values of $F_{\text {st }}$ and 
$\mathrm{R}_{\mathrm{st}}$ (calculated using the molecular variance function - AMOVA). Cluster analysis by the method of J.K. Pritchard et al. (15) was performed using the software Structure v. 2.3.1; the value of individuals' likelihood factor in population (Q) was calculated in Admixture Model and Correlation Model without introducing the preliminary data on their membership in particular populations for the number of populations $(\mathrm{k})$ equal to 2, 5, 10, and 17. Genetic distances were determined as described by M. Nei (16). A phylogenetic tree was constructed using the unweighted pair group method with arithmetic mean (UPGMA, software Past v. 2.15).

Results. Characteristics of the studied populations with corresponding numbers of tested samples are shown in Table 1.

Origin of evaluated groups of Large White (LW) and Yorkshire (Y) pig breeds

\begin{tabular}{|c|c|c|c|}
\hline № population & Breed & Country of origin & $n$ \\
\hline 1 & LW & "Hypor B.V." (Canada) & 100 \\
\hline 2 & $\mathrm{Y}$ & Breeding farms of Prince Edward Island (Canada) & 15 \\
\hline 3 & $\mathrm{Y}$ & Domestic breeding with admixture of European bloods (Czech Republic) & 43 \\
\hline 4 & LW & "DanBred" (Danish Pig Research Centre, Denmark) & 26 \\
\hline 5 & LW & Domestic breeding with admixture of European bloods (Samara province, Russia) & 24 \\
\hline 6 & $\mathrm{Y}$ & Domestic breeding with admixture of European bloods (Samara province, Russia) & 20 \\
\hline 7 & $\mathrm{Y}$ & "Canadian Centre for Swine Improvement "(Canada) & 16 \\
\hline 8 & LW & Domestic breeding with admixture of European bloods (Belgorod province, Russia) & 52 \\
\hline 9 & LW & "Rhg Hirschmann Hybrid GmbH" (Germany) & 104 \\
\hline 10 & $\mathrm{Y}$ & $\begin{array}{l}\text { Domestic breeding with admixture of European ("Cooperl Ark Atlantique", France) } \\
\text { bloods (Orenburg province) }\end{array}$ & 37 \\
\hline 11 & LW & "Cooperl Ark Atlantique" (France) & 29 \\
\hline 12 & LW & "Hermitage Genetics" (Ireland) & 61 \\
\hline 13 & LW & Domestic breeding with admixture of European bloods (Bryansk province) & 78 \\
\hline 14 & LW & Domestic breeding with admixture of European bloods (Bryansk province) & 80 \\
\hline 15 & $\mathrm{Y}$ & "Norsvin Lietuva" (Lithuania) & 58 \\
\hline 16 & LW & $\begin{array}{l}\text { Ukrainian breeding with admixture of European (England, Denmark, France) bloods } \\
\text { (Ukraine, Zaporozhsky Krai) }\end{array}$ & 72 \\
\hline 17 & LW & Hungarian breeding (Hungary) & 22 \\
\hline Total & & & 837 \\
\hline
\end{tabular}
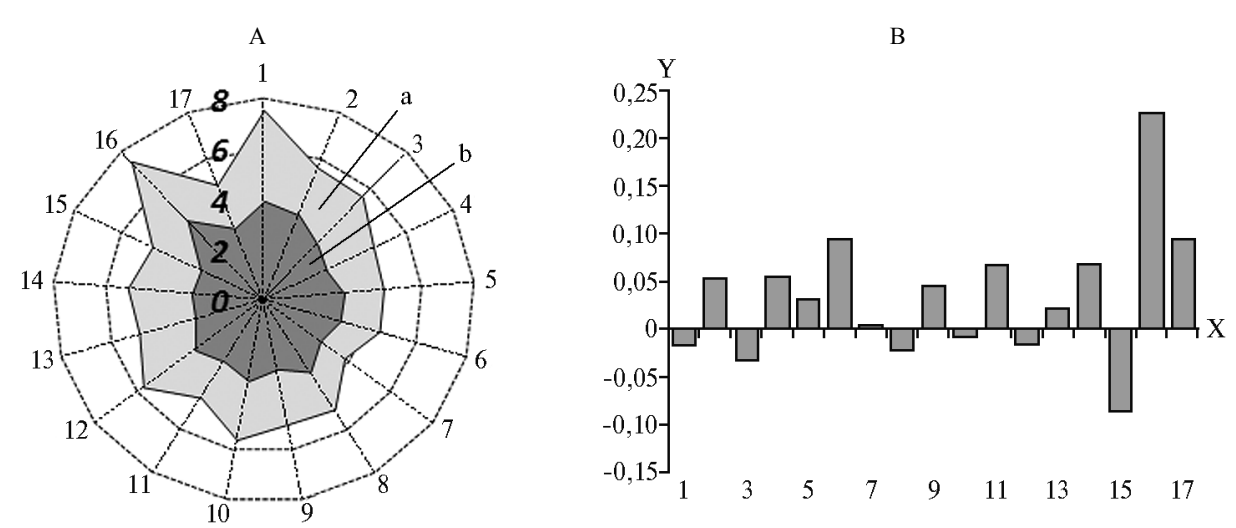

Fig. 1. Allelic profiles for 11 microsatellites (A) and deficit $(«+») /$ excess $(«-»)$ of heterozygotes (B) in studied populations of Large White and Yorkshire pigs: axes $\mathrm{X}$ - number of a studied population, see Table (A and $\mathrm{B}$ ); axes $\mathrm{Y}$ - number of alleles per locus of microsatellites (A, a - average number of alleles, b - average number of effective alleles, $0,2,4,6$, and 8 - scale of values) - and fixation index $F_{\text {is }}(B)$.

The average number of alleles per microsatellite locus (Figure 1, A) ranged from $3,8 \pm 0,5$ to $7,5 \pm 0,5$ (resp., populations ${ }^{11} 7$

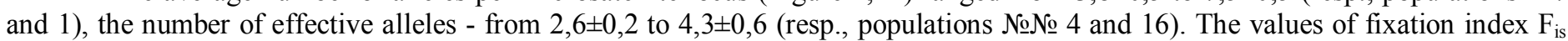
(Fig. 1, B) have revealed the deficit of heterozygotes exceeding $5 \%$ in 7 of the 17 studied populations (№№ 2, 4, 6, 11, 14, 16, and 17), which was greatest in the population № $16(22,5 \%)$. The excess of heterozygotes exceeding $5 \%$ was observed in the population ${ }^{1}$ $15(8,6 \%)$. In 15 of the 17 studied groups (except populations № 2 and № 7) for several loci there was observed a highly reliable (p $<0,01$ and $p<0,001$ ) deviation from the gene equilibrium of microsatellite loci. The maximum number of loci with such deviation was found in populations № 13 and № 16 (resp., 6 and 7 loci). No correlations between the nature of heterozygosity (deficit or excess) and the shift of genetic balance was revealed.

Private alleles were found in 11 of the 17 studied populations; most of them occurred with a frequency less than $5 \%$. The maximum number of alleles (11 of 34) were identified in the Ukrainian population (№ 16), which, most likely, resulted from the absence of gene exchange with other studied populations. In four populations (№№ 1, 2, 12, and 16) private alleles occurred with a frequency $>5 \%$ (they can be considered as specific for these populations): № 1 - allele 243 in locus SO355 (5,6\%), № 2 - 244 in locus SO228 (6,7\%), № 12 - 119 in locus SW72 (5,1\%), ${ }^{1} 16-97$ in locus SW72, 118 in locus SW951, 87 in locus SW240, and 93 in locus SW936 (resp., 8,7; 7,6; 5,5; 6,3\%).

The analysis of allelic diversity has shown that interpopulation differences amounted to $24,2 \%$ of the total variability $\left(\mathrm{R}_{\mathrm{st}}=\right.$ $0,242$ with $\mathrm{p}=0,01)$. In paired comparison, the value of $\mathrm{F}_{\mathrm{st}}$ indicated that the greatest influence on genetic variability over the total sample population was provided by populations originated from Canada and France $\left(\mathrm{F}_{\text {st }}\right.$ of № 7 and № 11: resp., $0,134 \pm 0,007$ and $0,123 \pm 0,006$ ), Bryansk province ( $\mathrm{F}_{\text {st }}$ of № 13 and № 14: resp., $0,125 \pm 0,006$ and $0,122 \pm 0,006$ ), and Ukraine ( $\mathrm{F}_{\text {st }}$ of № 16 and № 17: resp., $0,115 \pm 0,005$ and $0,119 \pm 0,005$ ). The assessment criterion $\mathrm{R}_{\mathrm{st}}$ (AMOVA) was calculated considering variation in both frequency and length of microsatellite alleles; according to $\mathrm{R}_{\mathrm{st}}$, the greatest influence on diversity over the total sample was provided by "Hypor BV" population (№ 1, $\left.R_{\mathrm{st}}=0,338 \pm 0,054\right)$, along with a significant contribution of "DanBred" pigs $\left(№ 4, R_{\mathrm{st}}=0,269\right)$. In general, the observed trends were similar to abovementioned: the values of $\mathrm{R}_{\text {st }}$ for populations №№ 7, 11, 13, 14, and 17 were equal to, resp., 0,$281 ; 0,263 ; 0,251 ; 0,244 ; 0,267$, while in the other groups $\mathrm{R}_{\mathrm{st}}$ ranged from 0,139 to 0,223 .

Figure 2 shows clustering of the studied populations as described by J.K. Pritchard et al. (15) with the number of clusters $\mathrm{k}=$ $2,5,10$, and 17, figure 3 - phylogenetic tree constructed upon the data of phylogenetic analysis according to M. Nei (16).

For the number of studied populations $\mathrm{k}=17$ (Fig. 2, D), none of them formed independent clusters at $\mathrm{Q}=0,75$. This fact 
probably indicates a common origin of these groups as members of breeds derived from one root. Clustering for $\mathrm{k}=2$ (Fig. 2 , A) has revealed a genetic isolation of two Canadian populations relative to other studied groups: their $\mathrm{Q}_{2 / 2}$ were equal to, resp., 0,949 (№ 1 ) and 0,916 (№ 2). This cluster with high values of $\mathrm{Q}_{2 / 2}$ also included the population of pigs from Prince Edward Island (Canada, № 7), “Cooperl Ark Atlantique” (France, № 10), as well as domestic and Ukrainian populations with admixture of French bloods (№ 11 and № 16): their $\mathrm{Q}_{2 / 2}$ were equal to, resp., 0,452;0,554;0,642;0,771. These populations are shown as individual subcluster of the phylogenetic tree (Fig. 3). The distribution of clusters for $\mathrm{k}=5$ (Fig. 2, B) has proved a specific origin of "Hypor BV" population (№ $\left.1, \mathrm{Q}_{2 / 5}=0,858\right)$, probably owing to a closed system of breeding in a number of generations. This population was genetically isolated from the other 15 , which can be seen in relatively low values peculiar to members of this cluster $\left(Q_{2 / 5}=0,021-0,174\right)$ and close to the only population of Canadian origin (№ 2) $\left(\mathrm{Q}_{2 / 5}=0,424\right)$, which, apparently, resulted from their geographic commonness.
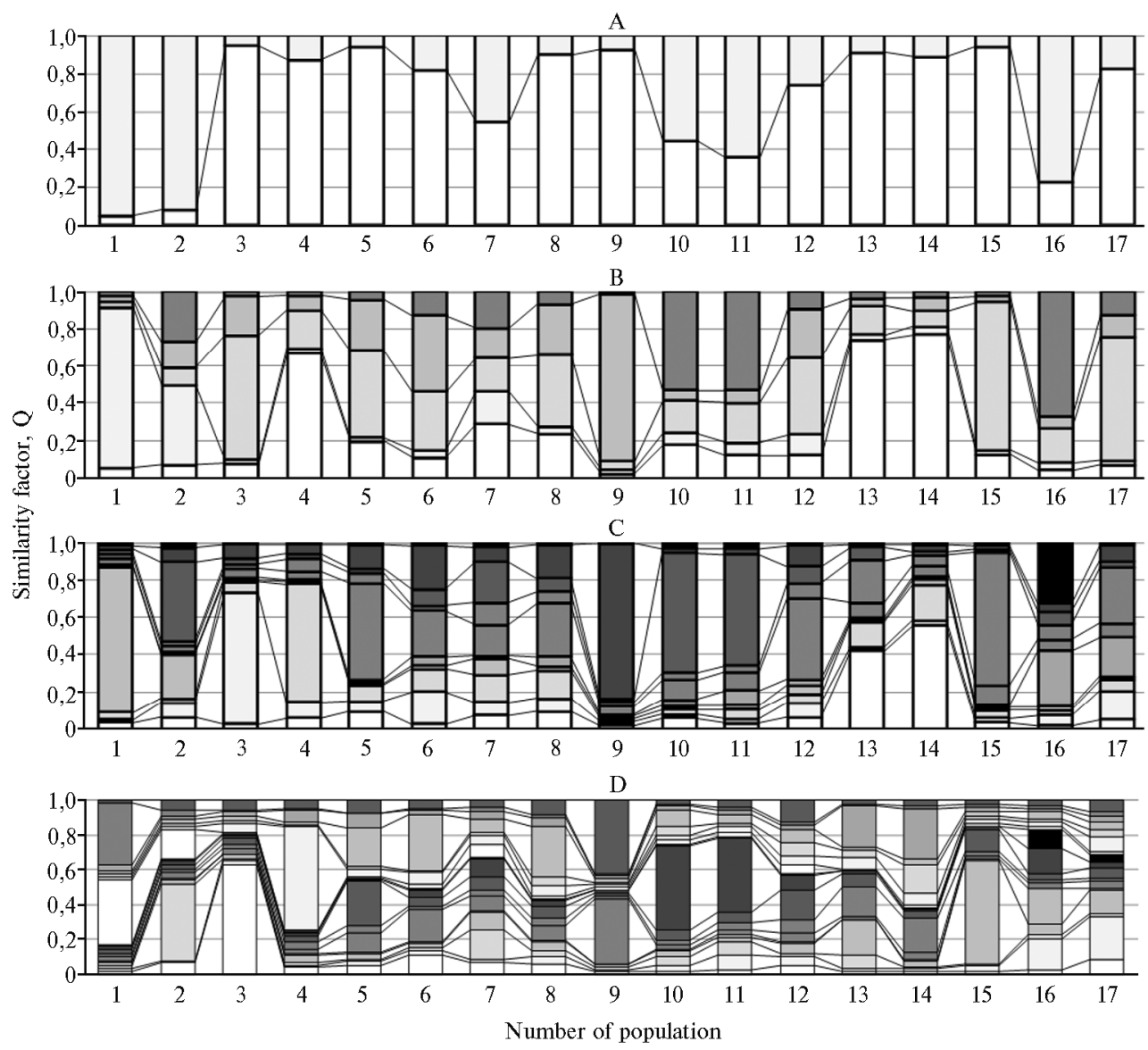

Fig. 2. Cluster analysis of studied populations of Large White and Yorkshire pigs according to J.K. Pritchard et al. (15) for 11 microsatellite loci: $\mathrm{A}-\mathrm{k}=2, \mathrm{~B}-\mathrm{k}=5, \mathrm{C}-\mathrm{k}=10, \mathrm{D}-\mathrm{k}=7$.

The similar trend was observed for $\mathrm{k}=10$ (Fig. 2, C) and $\mathrm{k}=17$ (Fig. 2, D). In the case of $\mathrm{k}=10$, Q $4 / 10$ in populations № 1 and № 2 was equal to, resp., 0,780 and 0,237, while for other populations of this cluster $\mathrm{Q}_{4 / 10}$ ranged from 0,011 to 0,087 . For $\mathrm{k}=17$ $\mathrm{Q}_{11 / 17}$ was, resp., 0,373 and 0,167, while in other members of this cluster - much lower $(0,010-0,078)$. The population of pigs "Rhg Hirshman Hybrid GmbH” (№ 9) was found to be genetically isolated according to its Q in the corresponding cluster at $\mathrm{k}=5\left(\mathrm{Q}_{4 / 5}=\right.$ $0,900), \mathrm{k}=10\left(\mathrm{Q}_{9 / 10}=0,834\right)$ and $\mathrm{k}=17\left(\mathrm{Q}_{17 / 17}=0,424\right)$, while in other populations these indices varied, resp., from 0,027 to 0,411 , from 0,020 to 0,234 , and from 0,017 to 0,122 . Relatively high values of $\mathrm{Q}$ in their clusters were observed in populations from Chuvashia (№ 3, $\mathrm{Q}_{1 / 17}=$ 0,630), “Norsvin Lietuva” (№ 15, $\left.\mathrm{Q}_{4 / 17}=0,594\right)$ and the Danish Pig Research Center $\left(№\right.$ 4, $\left.\mathrm{Q}_{12 / 17}=0,592\right)$; in the other studied populations $Q$ was equal to, resp., 0,015-0,110, 0,017-0,202 and 0,014-0,088. This fact can be assumed as an evidence of genetic isolation of these populations. 


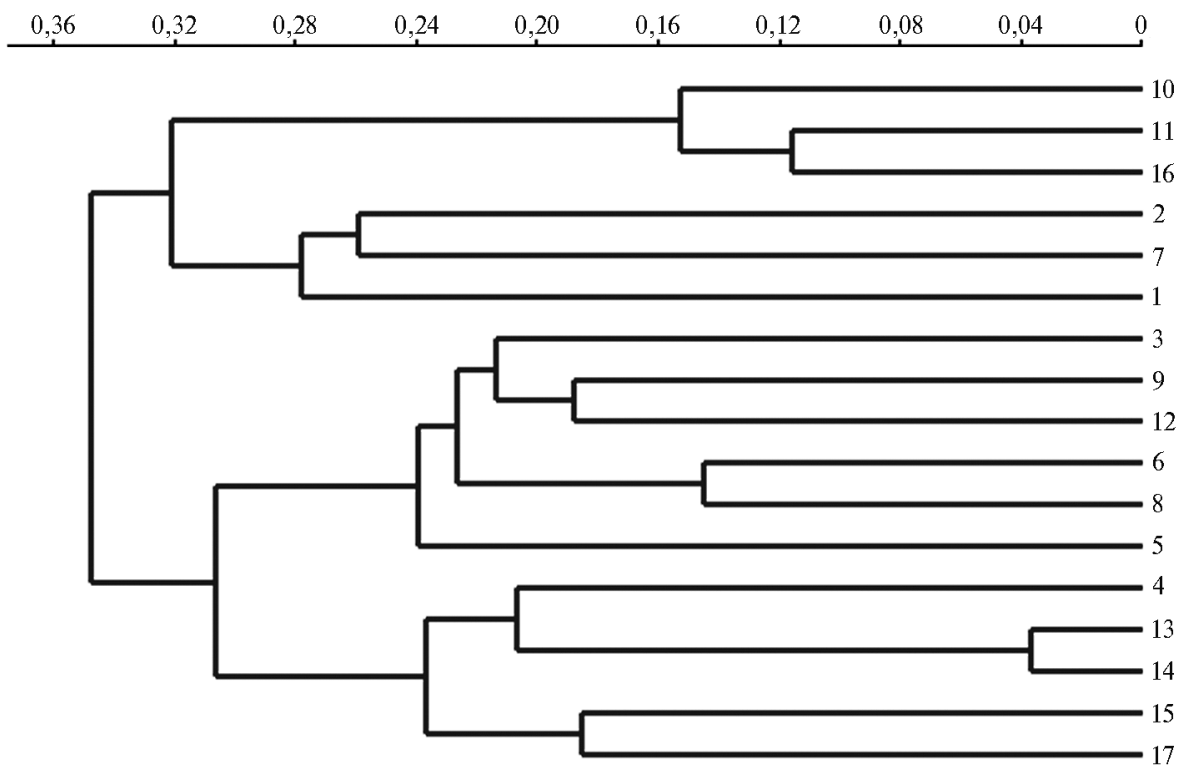

Fig. 3. Dendrogram of phylogenetic relations between studied populations of pigs (№№ 1-17, see Table) constructed according to M. Nei (16) by the method of unweighted pairwise group median analysis (UPGMA) based on microsatellite examination of 11 loci (axis $\mathrm{X}$ - genetic distances).

The structure of phylogenetic tree (Fig. 3) was consistent with the abovementioned regularities and reflected the origin of studied populations. Thus, the branch formed by populations №№ 1,2, and 7, was of a common geographical origin (Canada), while №№ 10, 11, and 16 were pigs of French breeding $\left({ }^{1} 10\right)$ and local groups with the admixture of French bloods (№№ 11 and 16). Apparently, these populations appeared in one subcluster because Yorkshire boars of French origin were intensely used in breeding programs in Canadian swine-breeding farms (17). The second subcluster shows several domestic population improved through the use of European bloods (№№ 3, 5, 6, and 8), as well as populations from Germany (№ 9) and Ireland (№ 12). The third subcluster shows the branch represented by highly specialized populations of private European enterprises (№№ 4, 15, and 17), and another branch of two domestic populations from Bryansk province (№ 13, № 14) - descendants of crosses with European boars.

It should also be noted that populations of Large Whites and Yorkshires and are not located separately on the phylogenetic tree, which proves their common origin.

Thus, the obtained results show that the study of a large number of geographically isolated populations provides the most complete characterization of the allele pool of breeds. Microsatellite profiles can serve as appropriate criteria for evaluation of animal populations' state and phylogenetic relations within a breed as an evidence of their origin.

\section{REFERENCES}

1. Tapio M., Ozerov M., Tapio I., Toro M.A., Marzanov N.S., Ginkulov M., Goncharenko G., Kiselyova T., Murawski M., and Kantanen J., Microsatellite-Based Genetic Diversity and Population Structure of Domestic Sheep in Northern Eurasia, BMC Genetics, 2010, vol. 11, pp. 76-86.

2. Dolmatova I.Yu., Zinovyeva N.A., Traspov A., Gorelov P.V., Ilyasov A.D., and Gladyr E.A., Allele Pool Characteristics of Bashkiria Population of Simmental Cattle Using Microsatellites, S.-kh. biol., 2011, vol. 6, pp. 70-74.

3. Ivanchuk V.A., Large White Pig in Russia, Svinoferma, 2011, vol. 2, pp. 24-34.

4. Kudryavtsev P.N., Plemennoye delo v svinovodstve (Pedigree Swine-Breeding), Moscow, 1948.

5. Bogdanov E.A., Razvedenie krupnykh yorkshirov (Breeding Large Yorkshires), 1922.

6. Kabanov V.D., Svinovodstvo (Swine-Breeding), Moscow, 2001.

7. Ivanchuk V.A., Large White Pig in Russia, Svinoferma, 2011, vol. 3, pp. 20-24.

8. Tautz D., Hypervariability of Simple Sequences as a General Source for Polymorphic DNA Markers, Nucl. Acids Res., 1989 , vol. 17, pp. 6463-6471.

9. Gladyr E.A., Zinovyeva N.A., and Grem G., Characterization of the Gene Pool and Identification of Genealogical Relations of Sheep Breeds in Russia Using DNA-Microsatellites, Dokl. RASKhN, 2004, vol. 2, pp. 26-29.

10. Proskurina N.V., Tikhomirova T.I., Gladyr E.A., Larionova P.V., and Zinovyeva N.A., Comparative Analysis of Informativeness of Erythrocytes Antigens and DNA-Microsatellites as Genetic Markers in Breeding-Pedigree Work with Pigs of Canadian Selection S.-kh. biol., 2007, vol. 6, pp. 41-47.

11. Strekozov N.I., Zinovyeva N.A., Gorelov P.V., Listratenkova V.I., Konovalova E.N., Chernushenko V.K., and Ernst L.K., Genetic Characterization of New Types of Brown Swiss and Sychevskaya Breeds Using Polymorphism of Microsatellites, S.-kh. biol., 2009, vol. 2, pp. 10-15.

12. Gladyr E.A., Gorelov P.V., Maurcheva V.N., Shakhin A.V., Chinarov Yu.I., and Zinovyeva N.A., Effectiveness Evaluation of Test System Based on Microsatellites for DNA Expertise in Cattle, Dostizheniya nauki i tekhniki APK, 2011, vol. 8, pp. 51-54

13. Zinovyeva N.A. and Gladyr E.A., Genetic Evaluation of Agricultural Animals: the Use of Microsatellite Test System, Dostizheniya nauki i tekhniki APK, 2011, vol. 9, pp. 19-20.

14. Weir B., Analiz geneticheskikh dannykh (Genetic Data Analysis), Moscow, Moscow, 1995.

15. Pritchard J.K., Stephens M., and Donnelly P., Inference of Population Structure Using Multilocus Genotype Data, Genetics, 2000 , vol. 155 , pp. 945-959.

16. Nei M., Tajima F., and Tateno Y., Accuracy of Estimated Phylogenetic Trees from Molecular Data, J. Mol. Evol., 1983, vol. 19, pp. 153-170.

17. Canadian Livestock Records Corporation Website, http://www.clrc.ca/index2010.shtml. 